\title{
Production of Single- Cell Protein from some Fruit peels
}

\author{
Amr Salem Awad, Salah Mosatafa Saad, Enas Mekawi and Nadia Yehia Attia* \\ Agriculture Biochemistry Department, Faculty of Agriculture, Benha University, Egypt \\ Corresponding author: amr.salem@ fagr.bu.edu.eg
}

\begin{abstract}
The bioconversion of various wastes such as fruit peels into some valuable products such as single-cell protein (SCP) has simultaneous potential to resolve nutritional protein deficiency worldwide. The shortage by obtaining an economical product for food and feed, as well as the mitigation of environmental pollutants to a large extent through the optimization of these residues, which serve as substrates for the production of a product with a high nutritional value. Therefore, the current study aimed to evaluate the feasibility of using fruit peels such as orange peel and pomegranate and their mixture through chemical treatment concentrations of dilute hydrochloric acid as well as thermal treatment by autoclave to obtain the highest concentration of sugars needed for yeast growth and the evaluation of biomass yields as a single-cell protein (SCP). The results showed that orange and pomegranate peels treated with different concentrations of 10, 20 and 30\% hydrochloric acid had the highest yield of reducing sugars $(4.89 \mathrm{~g} / 100 \mathrm{~g}$ peel) obtained from orange peels treated with $10 \%$ acid concentration. After that, a comparison was made between the treatment with the best concentration of acid $(\mathrm{HCl} \mathrm{10 \% )}$ ) and the thermal treatment by autoclaving for orange peels, pomegranate peels and a mixture of them, so the treatment with acid $(\mathrm{HCl} \mathrm{10 \% )}$ for the mixture had the highest concentration of reducing sugars, followed by orange peels (5.90 and $4.87 \mathrm{~g} / 100 \mathrm{~g}$ peels) respectively. But it was found that this treatment affects the growth of Saccharomyces cerevisiae later compared to the thermal treatment. After that, the media were prepared from orange peels and pomegranate peels, mixed with acid ( $\mathrm{HCl} \mathrm{10 \% )} \mathrm{and} \mathrm{heat} \mathrm{treatment,}$ and salts were added to one of them and the other without salts. The results were in favor of the thermal treatment. The orange peels thermal treated without salts gave the largest amount of protein, followed by the mixture without salts, then the mixture with salts that were thermal treated $(9.39,8.107$ and $8.02 \mathrm{~g} / \mathrm{L})$ respectively.
\end{abstract}

Keywords: Single cell protein; Saccharomyces cerevisiae; orange peels; pomegranate peels; chemical and thermal treatments

\section{Introduction}

Frequent population growth in developing countries, this led to the search for alternative food sources rich in protein, whether for humans or animals. It is a major problem of protein deficiency in the world for humans because protein is an essential part of life as a dietary supplement. Many poor countries face food problems and nutrient deficiencies. The single- cell protein is also called microbial protein which can be produced by fungi, yeast and bacteria (Saeed et al. 2020). The different microorganisms used in the production of single- cell protein (SCP) are yeast (Saccharomyces, Candida, etc.), molds (Fusarium, Trichoderma, Rhizopus, etc.) algae (Chlorella, Spirulina, etc.), and bacteria (Alcaligenes, Silomonas, etc.). Microorganisms can use a variety of substrates such as agricultural waste which aid in the decomposition of pollutants (Nasseri $\boldsymbol{e t}$ al. 2011).

This microbial protein that obtained from organisms are very rich in nutritional compounds such as protein, minerals, carbohydrates, lipids, vitamins and amino acids and these are also used as good supplements of diet, it has high nutritional benefits to overcome the problems of protein deficiency in foods used for humans and animals. It is not seasonal production. This system is totally environment friendly and has a low cholesterol level and it is overall a better method to produce protein. Saccharomyces cerevisiae could be suitable for singlecell protein production from cheap waste products [EIrhman et al. 2016; Saeed et al. 2020]. Another advantage of SCP is the abundance of essential amino acids such as methionine and lysine, which are often limited in animal and vegetable food. Single cell protein is also an important mode in food replacement for some of the more expensive food sources such as fish, flour, beans and some meat. Single cell protein has become one of the most important topics and ways to solve some food problems (Zhou et al. 2017).

In recent years, $S$. cerevisiae has become a suitable plant the cells for the biosynthesis of many important bio-compounds (Carsanba et al. 2021). S. cerevisiae, a 
model organism in biology (Fakult, 2012). Some of the modified proteins can be used in the tumor mechanism through the regulation of Lysine protein alterations in cancer-related pathways. This indicates that it can work mutated proteins, new potential cancer drivers that could be used for diagnosis biomarkers in clinical practice (Chen et al. 2018).

S. cerevisiae is a species of yeast and it is eukaryotic as a model organism that called baker's yeast. $S$. cerevisiae is the best studied eukaryote and a valuable tool for most aspects of basic research on eukaryotic organisms (Parapouli et al. 2020).

Saccharomyces cerevisiae (Baker's yeast) is one of the most important and widely used cell factories for protein recombination production (Huang et al. 2018). $S$. cerevisiae is very important for single-cell protein production due to its ease of harvest, low amounts of nucleic acids, efficient mix of amino acids, and large size. This is considered one of the solutions in the third world countries and developing countries that suffer from food shortages and malnutrition problems (Sciences et al. 2011).

S. cerevisiae and some economically important fungi can be successfully grown in some fruit peels waste media such as mango wastes, Pineapple, spoilt tomato fruit, Papaya, carrot, green Banana, yellow Banana, orange, coconut wastes, pomegranate, sugarcanes waste, apple, tomato, wheat straws wastes and pea peels. Effect of substrate concentration revealed that biomass concentration an increased with increase in substrate concentration [Ahuja and Kumari, (2019); Khan et al. 2010; Milala et al 2018; Saeed et al. 2020].

These cellulosic substrates usually have a lot of lignin content which prevents the process of cracking by microorganisms. Thus, enzymatic, acidic, or basic methods of enzymatic treatment and dilute acid followed by sterilization were necessary to quantify these wastes and obtain higher yields from sugar reduction and hence higher ethanol production. Dilute $\mathrm{HCl}$, sulphuric acid, alkaline treatment, and thermal hydrolysis (autoclaving), respectively, proved to give a good result where significant amounts of reducing sugars were obtained at the end of the saccharification process [Abdul and Ibrahim, (2017); John et al. 2017; Vázquez et al. 2017]. Thus, the single- cell protein production by yeast depends on the growth substrates or media composition (Mondal et al. 2012).

\section{Materials and Methods}

Collection of fruit peels and Microorganism culture
The pomegranate peels and or fruit peels were collected from the local markets of Albuhayra, Egypt in 2019. The microorganisms used to ferment fruit wastes was $S$. cerevisiae obtained from Department of Microbiology, Agriculture, Benha University. The yeast strain was grown on Yeast Extract Potato Dextrose Agar (YPDA) and sub-cultured every 3 weeks and incubated at $28-32^{\circ} \mathrm{C}$. All Chemical were analytical grade and purchased from Sigma Company.

\section{Preparation of substrates and fruit peels hydrolysate}

Pomegranate and orange fruit are collected and washed several times with water, to remove dust particles. Then were manually peeled and separated, then cut into small pieces with a knife. The pieces of peels are put in dark place until aerial dryness. The dry peel pieces were blended into smooth powder using a blender (model-brown) and sieved through a mesh screen. The samples were prepared, packed in transparent polythene bags and stored at room temperature until further study. S. cerevisiae lacks the enzyme system which hydrolyzes the polysaccharides into monosaccharide. The fruit peels were used as a substrate for production of single- cell protein production (SCP) after chemical and heat pretreatment.

\section{Chemical pretreatment}

\section{Determination of the best concentration of $\mathrm{HCl}$ for} cellulose chemical hydrolysis

The peels were degraded to convert cellulose content into more available sugars by chemical treatments with little modification to the procedure of (Lenihan et al. 2010). Twenty $\mathrm{mL}$ of 10, 20 and $30 \%$ (w/v) $\mathrm{HCl}$ were added to each $(10 \mathrm{~g})$ of orange or pomegranate peels powder in the conical flasks. The mixtures were placed in a water bath at 100,87 and $75^{\circ} \mathrm{C}$ for one hour, respectively. After being allowed to cool, it was filtered through Whatman No. 1 filter paper under vacuum. The filtrates were diluted with distilled water for $100 \mathrm{~mL}$ and determined the reducing sugars (Saywell and Phillips, 1934).

\section{Thermal pretreatment}

The method (Khan et al. 2010) was used with some modifications. $200 \mathrm{~mL}$ of distilled water was added to the each $16 \mathrm{~g}$ from peels powder of orange, pomegranate and a mixture of them (1:1) in a conical flasks. The mixtures were autoclaved at $121^{\circ} \mathrm{C}$ for 30 mints. After being allowed to cool, they were filtered through Whatman filter paper under vacuum. A sample 
of filtrates was used to determine the reducing sugars (Saywell and Phillips, 1934).

\section{S. cerevisiae inoculum preparation}

For preparation of $S$. cerevisiae inoculum, sterilized potato dextrose broth media were inoculated with 3 days-old-culture of yeast and incubated at $27^{\circ} \mathrm{C}$ for $48 \mathrm{hr}$. The cell suspension was adjusted to a final concentration of 107 CFU. $\mathrm{mL}^{-1}$. The suspension inoculum was kept in a chiller at $4^{\circ} \mathrm{C}$ for further use.

\section{Fermentation process}

Submerged fermentations were carried out in Erlenmeyer flasks using four types of media. The first and the second of them were designed by the fruit peels (orange, pomegranate or mix) hydrolyzate that was produced from chemical or thermal pretreatment. Third and fourth had the following composition a (NH4) ${ }_{2} \mathrm{SO}_{4}$ $(0.2 \mathrm{~g}), \mathrm{KH}_{2} \mathrm{PO}_{4}(0.1 \mathrm{~g}), \mathrm{MgSO}_{4} .7 \mathrm{H}_{2} \mathrm{O}(0.05 \mathrm{~g}), \mathrm{NaCl}$ $(0.01 \mathrm{~g}), \mathrm{CaCl}_{2}(0.01 \mathrm{~g})$ made up to one liter with fruit hydrolysates $(\mathrm{FH})$ that produced from chemical or thermal pretreatment (Mondal et al. 2012).

In all the media, the initial $\mathrm{pH}$ was adjusted to 5.5 using $1 \mathrm{~N} \mathrm{HCl}$ and/or $1 \mathrm{~N} \mathrm{NaOH}$. Each medium $(98 \mathrm{~mL})$ was transferred into $250 \mathrm{~mL}$ Erlenmeyer flask and then autoclaved at $121^{\circ} \mathrm{C}$ for 15 minutes. Inoculum of $2 \mathrm{~mL}$ from the suspension of $S$. cerevisiae was aseptically transferred into each medium. Fermentation was carried out at $28^{\circ} \mathrm{C}$ under shaker condition.

\section{Determination of Yeast Biomass:}

At the end of incubation time after 8 days all cultures were centrifuged at $10,000 \mathrm{rpm}$ for 5 minutes. The supernatant was discarded, and the cell pellets were washed with sterile water. Before taking the weight of the biomass, it was transferred into an aluminum dish and was oven dried at $105^{\circ} \mathrm{C}$ for one hr. followed by cooling in desiccators to balance the temperature and weight (Prosser and Tough, 1991).

Statistical analysis
All the experimental results were presented by the average value of triplicates with mean \pm SD (standard deviation). The data were statistically analyzed using one-way analysis of variance (ANOVA) analysis and Duncan's multiple range tests (minimum significance threshold $P=0.05$ ) were used to compare the sets of means obtained from different experiments. $P^{\prime \prime}$ values for three replicates of the investigated parameters and were calculated. Using (Costate- 2008 software version 6.400 for Windows), Excel software (Microsoft Office Excel Worksheet (.xlsx), USA, 2013) was used to draw charts.

\section{Results}

\section{Reducing Sugar yield by Acid Hydrolysis}

Acid hydrolysis was applied to convert waste cellulose into monosaccharaides as reducing sugars that can be used as a good source of organic carbon for $S$. cerevisiae growth. Pretreatment by the acid hydrolysis was done at various concentrations of $\mathrm{HCl}(10 \%, 20 \%$, and $30 \% \mathrm{w} / \mathrm{v})$. The maximum reducing sugar obtained with pomegranate peel and orange peel hydrolyzed by $10 \%$ concentrated $\mathrm{HCl}$ was $3.959 \%$ and $4.88 \%$ respectively. Table 1 show the release of reducing sugar from orange peel and pomegranate peel was found to decrease as the concentration of acid increases. It may be because further oxidation of reducing sugar was happened with increasing acid concentration. In this experiment, the powdered peels were hydrolyzed using hydrochloric acid at various temperatures $100^{\circ} \mathrm{C}, 87^{\circ} \mathrm{C}$ and $75^{\circ} \mathrm{C}$ respectively. The particle size of substrate, residence concentrations and temperature play a crucial role in hydrolysis. Small particle size increases the exposed surface area which is available to react with hydrochloric acid. The residence concentration increases the contact concentration between substrate and acid. The temperature plays a crucial role in any biochemical reaction as the rate constant of hydrolyzed reaction depends on temperature. If the temperature increases, the rate also increases.

Table 1. Reducing sugar concentration (\%) produced from orange and pomegranate peels treated with various acid concentrations.

\begin{tabular}{llcl}
\hline & \multicolumn{3}{c}{ The concentration of reducing sugars $(\%)$} \\
\cline { 2 - 4 } Sample & $\mathbf{1 0 \%}$ HCl & $20 \%$ HCl & $30 \%$ HCl \\
\hline Pomegranate Peel & $3.959 \pm 0.09$ & $3.754 \pm 0.09$ & $3.625 \pm 0.09$ \\
Orange Peel & $\mathbf{4 . 8 8 8} \pm \mathbf{0 . 0 7}$ & $4.615 \pm 0.07$ & $\mathbf{4 . 3 3 0} \pm 0.07$ \\
\hline
\end{tabular}

Significant $p$ value $<0.05$. Data presented as mean \pm SD. 


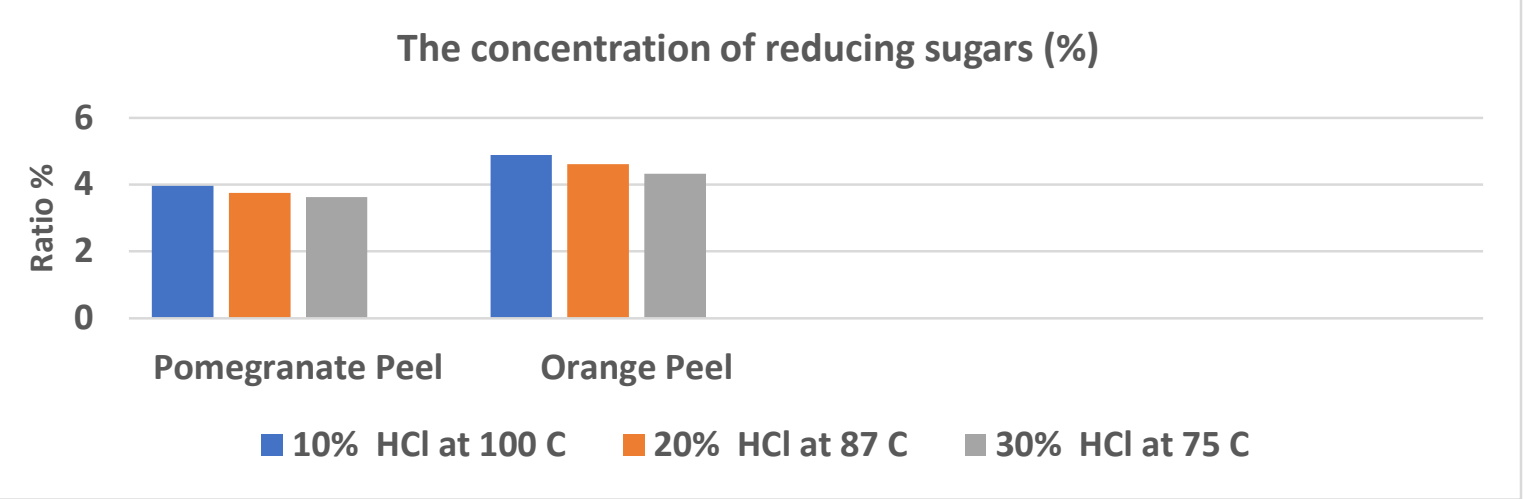

Figure 1. Reducing sugar production after acid treatment of orange and pomegranate peels.

Interestingly, under the same concentration of acid treatment and same temperature, orange and pomegranate peels differently influenced and gave a different amount of reducing sugar. However, by increasing acid concentration the oxidation of reducing sugar was noticed. The maximum reducing sugar $(4.88 \%$ and $3.959 \%)$ was obtained from the orange peel and Pomegranate Peel respectively, which were produced by $10 \% \mathrm{HCl}$ after one hour at $100^{\circ} \mathrm{C}$. Hence, this condition is considered to be optimum.

\section{Reducing Sugar from thermal and acid treatments of orange and pomegranate peels and their mixture}

A high level of reducing sugar was obtained after hydrolysis by thermal or autoclaved treatment. Therefore, thermal hydrolysis is able to extract reduced sugar even after acid hydrolysis of orange peel and pomegranate peel. The thermal treatment was used for further saccharification of lignocellulosic biomasses. The data in Table 2. show the maximum reducing sugar found during acid treatment were $5.90 \pm 0.09 \%$ and $4.86 \pm 0.07 \%$ of mix and orange peel respectively, while the maximum reducing sugar found during thermal treatment were $5.32 \pm 0.09 \%$ and $4.03 \pm 0.07 \%$ of mixture and orange peel respectively. The acid and thermal hydrolysis treatments of the samples were prepared in the optimum condition. However, acid hydrolysis is not normally recommended for saccharification due to liberation of furfural which turns down the next fermentation process. On the other hand, thermal hydrolysis is a biological process where the end products are environmentally friendly. These end products are less toxic which may negatively affect the next fermentation process.

Table 2. Reducing sugar produced from Pomegranate, Orange Peels and mixture by acid and thermal treatments.

\begin{tabular}{llll}
\hline & \multicolumn{3}{c}{ Concentration of reducing sugars (\%) } \\
\cline { 2 - 4 } Sample & Pomegranate Peel & Orange Peel & Mix \\
\hline HCl 10\% & $3.946 \pm 0.05 \mathrm{c}$ & $\mathbf{4 . 8 6 9} \pm 0.07 \mathrm{~b}$ & $5.902 \pm 0.09 \mathrm{a}$ \\
Thermal & $\mathbf{3 . 5 2 1} \pm \mathbf{0 . 0 5 \mathrm { c }}$ & $\mathbf{4 . 0 3 0} \pm \mathbf{0 . 0 7} \mathrm{b}$ & $5.321 \pm 0.09 \mathrm{a}$ \\
\hline
\end{tabular}

Significant $p$ value $<0.05$. Data presented as mean \pm SD.

A high percentage of efficiency was achieved from the thermal hydrolysis of mixture peels. Therefore, this condition is considered as the optimum condition for thermal treatment. Additionally, data in Fig.2 explicate that acid conversion for production of reducing sugar from the two kinds of peels and their mixture were found to be higher as compared to the thermal hydrolysis. Therefore, the highest percentage of reducing sugar is produced from the mixture of two kinds of peels by acid hydrolysis followed by thermal treatment. 


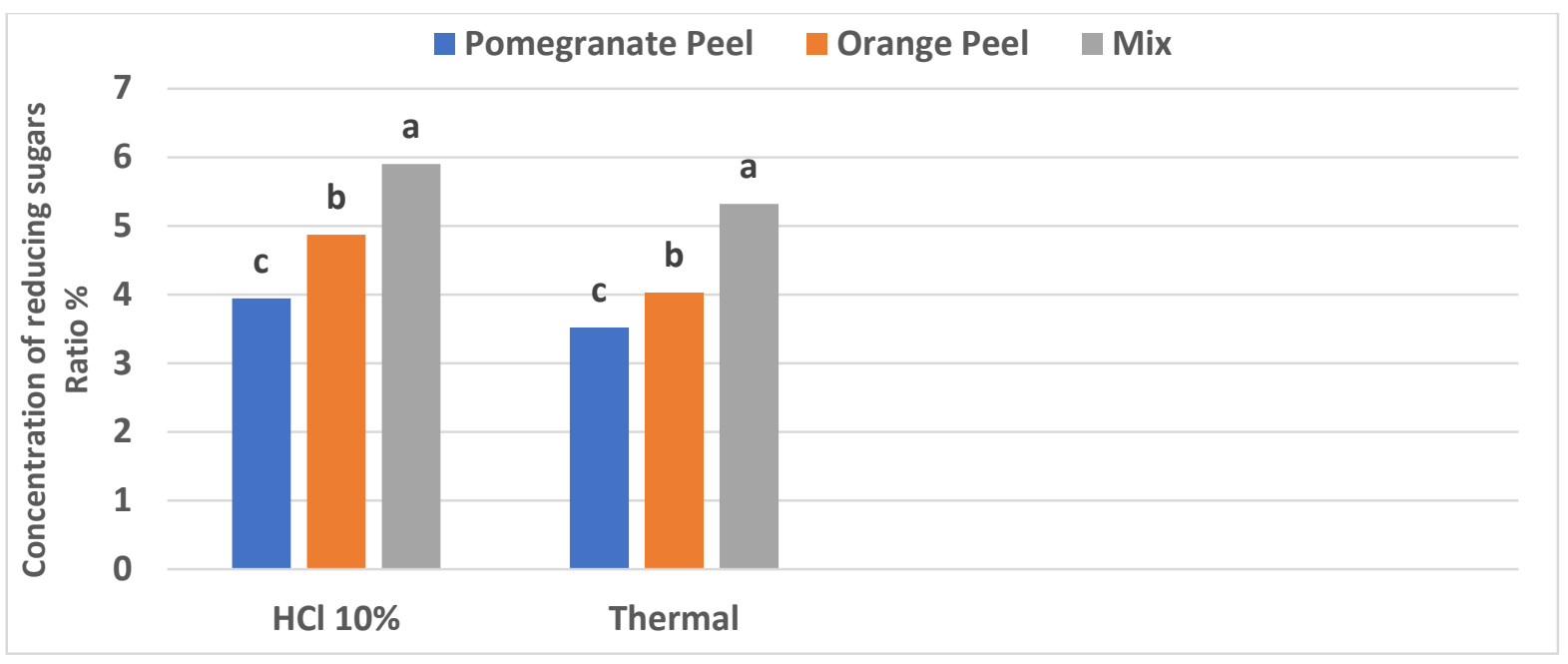

Figure 2. Reducing sugar production after acid and thermal treatments.

\section{Cell Proliferation and Protein Production}

Cell or biomass production of $S$. cerevisiae was performed based on the designed pattern (Table 3); 98 $\mathrm{mL}$ of sterile culture medium was added to each $250-\mathrm{mL}$ shake flask. After inoculation with $2 \mathrm{~mL}$ of $S$. cerevisiae cell suspension, all the shake flasks were incubated in a shaker incubator and $28^{\circ} \mathrm{C}$ for 8 days.

\section{Biomass weight:}

The maximum biomass weight of dried cell of $S$. cerevisiae at optimal condition was obtained equal to $9.388 \pm 0.091 \mathrm{~g} / \mathrm{L}$ of (orange peel) thermal-hydrolysate media. Basically, $S$. cerevisiae has considerable amounts of protein with some minerals, soluble fiber, and mono and poly saturated fatty acids (Yamada and Sgarbieri, 2005). While in this work all media prepared under the last same conditions Table 3 shows the results for all experiments of 1 to 12 were O.P HCl-hydrolysate with salts $4.869 \pm 0.199 \mathrm{~g} / \mathrm{L}$, O.P HCl-hydrolysate $3.642 \pm 0.135 \mathrm{~g} / \mathrm{L}$, O.P thermal-hydrolysate with salts $3.377 \pm 0.323 \mathrm{~g} / \mathrm{L}$, O.P thermal-hydrolysate $9.388 \pm 0.091$ $\mathrm{g} / \mathrm{L}$, (pomegranate peel) $\mathrm{HCl}$-hydrolysate with salts $6.082 \pm 0.173 \mathrm{~g} / \mathrm{L}$, P.P HCl-hydrolysat $5.547 \pm 0.164 \mathrm{~g} / \mathrm{L}$, P.P thermal-hydrolysate with salts $5.733 \pm 0.215 \mathrm{~g} / \mathrm{L}$, P.P thermal-hydrolysate $2.935 \pm 0.114 \mathrm{~g} / \mathrm{L}$, Mix $\mathrm{HCl}-$ hydrolysate with salts $3.983 \pm 0.069 \mathrm{~g} / \mathrm{L}$, Mix $\mathrm{HCl}-$ hydrolysat $4.915 \pm 0.099 \mathrm{~g} / \mathrm{L}$, Mix thermal-hydrolysate with salts $8.021 \pm 0.124 \mathrm{~g} / \mathrm{L}$ and Mix thermal-hydrolysate $8.107 \pm 0.153 \mathrm{~g} / \mathrm{L}$, respectively.

Table 3. weight of biomass produced from different media.

\begin{tabular}{llc}
\hline $\mathbf{N}$ & Sample name & Weight of biomass $(\mathrm{g} / \mathrm{L})$ \\
\hline 1 & O.P HCl-hydrolysate with salts & $4.869 \pm 0.199 \mathrm{e}$ \\
2 & O.P HCl-hydrolysate & $3.642 \pm 0.135 \mathrm{~g}$ \\
3 & O.P thermal-hydrolysate with salts & $3.377 \pm 0.323 \mathrm{~g}$ \\
4 & O.P thermal-hydrolysate & $\mathbf{9 . 3 8 8} \pm 0.091 \mathrm{a}$ \\
5 & P.P HCl-hydrolysate with salts & $\mathbf{6 . 0 8 2} \pm 0.173 \mathrm{c}$ \\
6 & P.P HCl-hydrolysate & $\mathbf{5 . 5 4 7} \pm 0.164 \mathrm{~d}$ \\
7 & P.P thermal-hydrolysate with salts & $\mathbf{5 . 7 3 3} \pm \mathbf{0 . 2 1 5 \mathrm { d }}$ \\
8 & P.P thermal-hydrolysate & $\mathbf{2 . 9 3 5} \pm 0.114 \mathrm{~h}$ \\
9 & Mix HCl-hydrolysate with salts & $\mathbf{3 . 9 8 3} \pm \mathbf{0 . 0 6 9 f}$ \\
10 & Mix HCl-hydrolysate & $\mathbf{4 . 9 1 5} \pm 0.099 \mathrm{e}$ \\
11 & Mix thermal-hydrolysate with salts & $\mathbf{8 . 0 2 1} \pm 0.124 \mathrm{~b}$ \\
12 & Mix thermal-hydrolysate & $\mathbf{8 . 1 0 7} \pm 0.153 \mathrm{~b}$ \\
\hline
\end{tabular}

Significant $p$ value $<0.05$. Data presented as mean \pm SD. 
Data showed the evaluation of thermal treatment in biomass production was evaluated, produced biomass weight of O.P thermal-hydrolysate media 9.388 \pm 0.091 with thermal hydrolysis standard deviation, which confirmed the relative susceptibility of fraction of full factorial methodology to determine the optimal culture medium composition in the present work. The second high yield obtained cell biomass weight in the present work $(8.107 \pm 0.153$ of $\mathrm{mix}$ thermal-hydrolysate at optimum conditions).

The variance of biomass yield between the differences media Fig. 3 shows that the O.P thermalhydrolysate was the better media that produced a high yield of a dry cell for $S$. cerevisiae as a single cell protein. The second media that produced high biomass was the mixture of pomegranate peel and orange peel (mix) without salts media treated with a thermal method, while the third highest yield produced from the Mix media with salts treated with thermal a method.

\section{Discussions}

The data found from this study shows that the production of single cell protein by microorganisms depends on the treatments of the fruit wastes by chemical methods such as diluted hydrochloric acid and thermally treated (autoclaving) to increase the concentration of reducing sugars that necessary for microbial growth [Azam et al. 2014; Mondal et al. 2012; Puri et al. 2020; Vázquez et al. 2017]. Where the best treatments for fruit peels were thermal treatment by autoclaving, compared to treatment with different concentrations of acid, in terms of cost, as well as preparing the appropriate media for the growth of $S$. cerevisiae free from the presence of acid, which may cause interference that leads to the inhibition of yeast growth (Vázquez et al. 2017).

The growth of $S$. cerevisiae increases with the increase in the concentration of reducing sugars in the environment and thus the amount of protein produced by the yeast increases (Hezarjaribi and Ardestani, (2016).

The amount of protein produced from the different media prepared from acid-treated and thermally treated for $S$. cerevisiae growth was compared by dividing it into four environments for each residue of fruit peels. The result was the media without salts in which yeast grew more than compared the results with various other studies [Mondal et al. 2012; Uchakalwar and Chandak, 2014], especially the thermal treated media without salts. The amount of protein produced was greater for orange peels, followed by mix and pomegranate peels.

\section{Conclusion}

It can be concluded that the most promising yield of single-cell protein production from $S$. cerevisiae by submerged fermentation of fruit peels. The degree of production of SCP depends on the type of substrate used and media composition. In addition to providing the carbon source available to living organisms represented in reducing sugars, and thus Promote sustainable consumption and production. The current study reveals that the fruit peels of oranges and pomegranates and their, combination can be used as a potential source product with a relatively high protein content using the various ingredients available in it, with the possibility of benefiting from the peels of the fruit in the production of valid proteins for feed and food. Hence, these peels must be used properly substrate for edible cellular biomass production from $S$. cerevisiae Instead of getting rid of it, and at the lowest financial cost, it can be used as a food supplement. Finally, the high yield and the growth of $S$. cerevisiae as single cell protein in the different media that prepared by thermal and acid treatment was produced from that media treated with thermal treatment for all wastes of orange peels, pomegranate peels and a mixture of them (1:1) with added salts and without salts. The results proved that autoclave/thermal treatment the best method to provide the optimum condition for microbial growth.

\section{Acknowledgment}

We would like to thank Dr. Hany Mohamed AbdelRahman, Agric. Microbiology Dept., Fac. Agric. Moshtohor, Benha Univ., for his time and efforts taken for laboratory support.

\section{References}

Abdul, J., \& Ibrahim, K. (2017). Production of Biofuels from Selected Cellulosic Waste materials55-46,(8)23.

Ahuja, S., \& Kumari, P. (2019). Production of Single Cell Protein from Fruit and Vegetable Waste using Saccharomyces cerevisiae. 8(02), 114-124.

Azam, S., Khan, Z., Ahmad, B., Khan, I., \& Ali, J. (2014). Production of Single Cell Protein from Orange Peels Using Aspergillus niger and Saccharomyces cerevisiae Pakistan Council of Scientific and Industrial Research Laboratories Complex,. $9(1), \quad 14-18$. https://doi.org/10.5829/idosi.gjbb.2014.9.1.82314 
Carsanba, E., Pintado, M., \& Oliveira, C. (2021). Fermentation Strategies for Production of Pharmaceutical Terpenoids in Engineered Yeast.

Chen, L., Miao, Y., Liu, M., Zeng, Y., Gao, Z., Peng, D., \& Hu, B. (2018). Pan-Cancer Analysis Reveals the Functional Importance of Protein Lysine Modification in Cancer Development. 9(July), 1-18. https://doi.org/10.3389/fgene.2018.00254

El-rhman, A., \& Food, S. (2016). Alkali Pretreated Rice Straw as an Inexpensive Substrate for SingleCell Protein Production by Saccharomyces cerevisiae. 96(1), 81-96.

Fakult, D. T. (2012). Single Cell Protein (SCP) Production from Date Juice.

Hezarjaribi, M., \& Ardestani, F. (2016). Single Cell Protein Production by Saccharomyces cerevisiae Using an Optimized Culture Medium Composition in a Batch Submerged Bioprocess. Applied Biochemistry and Biotechnology, 1336-1345. https://doi.org/10.1007/s12010-016-2069-9

Huang, M., Wang, G., Qin, J., Petranovic, D., \& Nielsen, J. (2018). Engineering the protein secretory pathway of Saccharomyces cerevisiae enables improved protein production. https://doi.org/10.1073/pnas.1809921115

John, I., Yaragarla, P., Muthaiah, P., Ponnusamy, K., \& Appusamy, A. (2017). Resource-Efficient Technologies Statistical optimization of acid catalyzed steam pretreatment of citrus peel waste for bioethanol production. 3, 429-433. https://doi.org/10.1016/j.reffit.2017.04.001

Khan, M., Khan, S. S., Ahmed, Z., \& Tanveer, A. (2010). Production of Single Cell Protein from Saccharomyces cerevisiae by utilizing Fruit Wastes. 1(2), 127-132.

Lenihan, P., Orozco, A., Neill, E. O., Ahmad, M. N. M., Rooney, D. W., \& Walker, G. M. (2010). Dilute acid hydrolysis of lignocellulosic biomass. 156 , 395-403. https://doi.org/10.1016/j.cej.2009.10.061

Milala, M. A., Yakubu, M., Burah, B., Laminu, H. H., \& Bashir, H. (2018). Production and optimization of single cell protein from orange peels by Saccharomyces cerevisiae. 3(October), 99-104.

Mondal, A. K., Sengupta, S., Bhowal, J., Bhattacharya, D. K., Engineering, B., \& Bengal, W. (2012). UTILIZATION OF FRUIT WASTES IN PRODUCING SINGLE CELL. 1(5), 430-438.

Nasseri, A. T., Rasoul-Amini, S., Morowvat, M. H., \& Ghasemi, Y. (2011). Single cell protein: production and process. American Journal of food technology, 6(2), 103-116.

Parapouli, M., Vasileiadis, A., \& Afendra, A. (2020). Saccharomyces cerevisiae and its industrial applications (Vol. 6, Issue January). https://doi.org/10.3934/microbiol.2020001

Prosser, J. I., \& Tough, A. J. (1991). Growth mechanisms and growth kinetics of filamentous microorganisms. Critical reviews in biotechnology, 10(4), 253-274.

Puri, S., Sarao, L. K., Kaur, A., Aggarwal, P., \& Jaswal, T. (2020). Comparative study of single cell protein production by utilising different fruit and vegetable wastes. 5-7.

Saeed, M. S., Saeed, A., \& Adnan, M. (2020). Production and Utilization of Single Cell Proteins An Overview. 1, 9-12.

Saywell, L. G., \& Phillips, E. P. (1934). Comparative Clarification of Sugar Solutions. Industrial \& Engineering Chemistry Analytical Edition, 6(2), 116-117.

Sciences, P., Bacha, U., Nasir, M., Khalique, A., Anjum, A. A., Jabbar, M. A., Sciences, A., \& Sciences, A. (2011). COMPARATIVE ASSESSMENT OF VARIOUS AGROINDUSTRIAL WASTES FOR SACCHAROMYCES CEREVISIAE BIOMASS PRODUCTION AND ITS QUALITY EVALUATION AS SINGLE CELL PROTEIN. 21(4).

Uchakalwar, P. R., \& Chandak, A. M. (2014). Production of Single Cell Protein from Fruits waste by using. 5, 770-776.

Vázquez, B. C., Roa-morales, G., Natividad, R., Balderas-hernández, $\mathbf{P}$., \& Saucedo-luna, J. (2017). Thermal Hydrolysis of Orange Peel and its Fermentation with Alginate Beads to Produce Ethanol. 12(2), 2955-2964.

Yamada, E. A., \& Sgarbieri, V. C. (2005). Yeast (Saccharomyces cerevisiae) protein concentrate: preparation, chemical composition, and nutritional and functional properties. Journal of agricultural and food chemistry, 53(10), 3931-3936

Zhou, Y. M., Chen, Y. P., \& Shen, Y. (2017). Single cell protein-feed: Taking orange waste as raw material for fermentation. In Advanced Materials and Energy Sustainability: Proceedings of the 2016 International Conference on Advanced Materials and Energy Sustainability (AMES2016) (pp. 323335). 


\section{إنتاج البروتين أحادي الخلية من بعض قثور الفاكهة

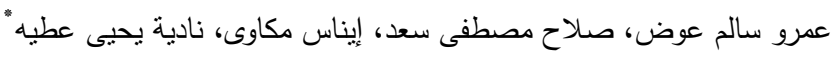

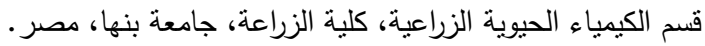

Corresponding author: amr.salem@ fagr.bu.edu.eg

التحويل الحيوي للنفايات المختلفة مثل قثور الفاكهة إلى بعض المنتجات القيمة مثل البروتين أحادي الخلية (SCP) لديه إمكانات متزامنة لحل نقص الفاء

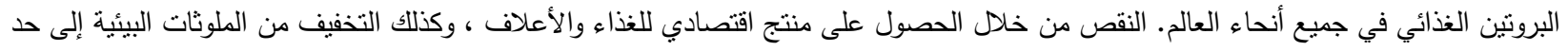
كبير من خلال الاستفادة المثلى من هذه المخلفات ، والتي تكون بمثابة ركائز لإنتاج منتج ذي قيمة غذائية عالية. لذلك هدفت الدراسة الحالية إلى تقييم

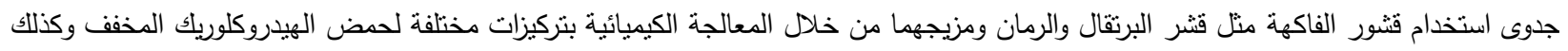

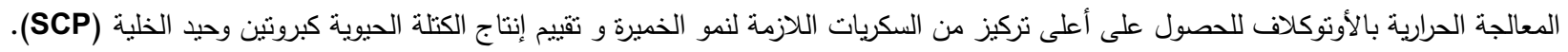

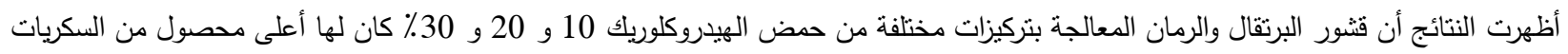

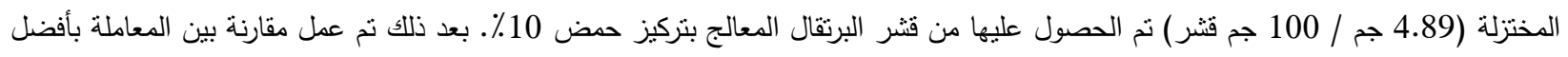

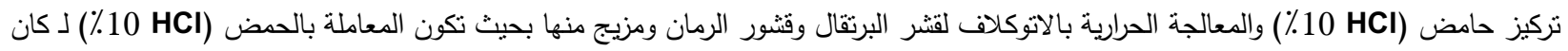

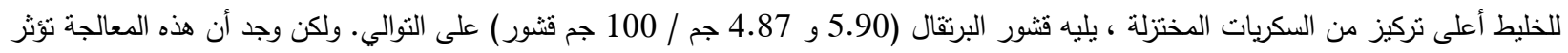

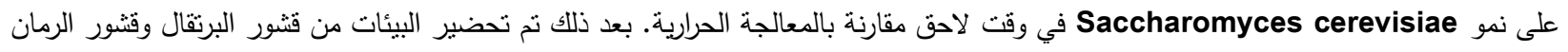

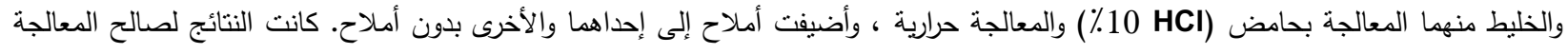

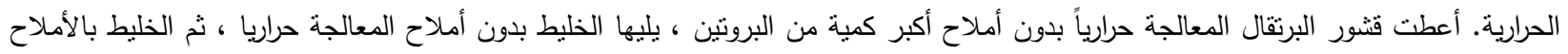

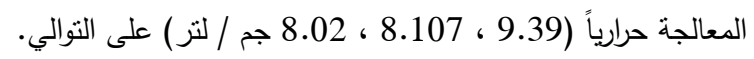

الكلمات الرئيسية: بروتين وحيد خلية ؛ خميرة Saccharomyces cerevisiae ؛ قثور البرتقال؛ قثشور الرمان؛ المعالجات الكيميائية والحرارية. 